\title{
ПРОБЛЕМИ ФОРМУВАННЯ ФІНАНСОВОГО ЗАБЕЗПЕЧЕННЯ РОЗВИТКУ ЛІСОГОСПОДАРСЬКИХ ПІДПРИЄМСТВ В УКРАЇНІ
}

\author{
PROBLEMS OF THE FORMATION OF FINANCIAL SUPPORT OF \\ THE FORESTRY ENTERPRISES DEVELOPMENT IN UKRAINE
}

Дубина М. В.

доктор економічних наук, професор, завідувач кафедри фінансів, банківської справи та страхування Національного університету «Чернігівська політехніка», Чернігів

ORCID: 0000-0002-5305-7815

\begin{abstract}
Зінкевич О. В.
здобувач,

кафредри фрінансів, банківської справи та страхування Національного університету «Чернігівська політехніка», Чернігів

Maksym Dubyna

Doctor of Economics, Professor, Head of the Department of Finance, Banking and Insurance Chernihiv Polytechnic National University, Chernihiv
\end{abstract}

Oleksandr Zinkevych

candidate

Department of Finance, Banking and Insurance, Chernihiv Polytechnic National University, Chernihiv

У статті розглянуто сучасні системні проблеми розвитку лісового господарства в Україні та виокремлено базові перешкоди удосконалення фрінансового забезпечення функціонування цієї галузі національного господарства. Встановлено, що в Україні на сьогодні використовується модель екстенсивного лісокористування, яка вже втратила свою актуальність, оскільки не дозволяє нарощувати виробництва продукції окресленої галузі, забезпечити їі довгостроковий розвиток, враховуючи незначні площі лісів на території країни. Відповідно, впровадження принципів саме інтенсивного лісокористування є єдиним шляхом для активізації роботи лісогосподарських підприємств, забезпечення зростанні рівня їхнього фрінансового забезпечення. У статmі констатовано, що удосконалення також потребує механізм фрінансування окресленої галузі, який не відповідає основним принципам фрункціонування ринкової економіки. Також конкретизовані проблеми в цьому напрямку розвитку лісового господарства. Ключові слова: лісове господарство, фінансове забезпечення, галузь лісового господарства, інтенсивне лісокористування, фрінансування лісогосподарських підприємств.

В статье рассмотрены современные системные проблемы развития лесного хозяйства в Украине и выделены базовые препятствия совершенствования фринансового обеспечения фрнкционирования этой отрасли национального хозяйства. Установлено, что в Украине на сегодня используется модель экстенсивного лесопользования, которая уже потеряла свою актуальность, поскольку не позволяет наращивать производство продукции данной отрасли, обеспечить ее долгосрочное развитие, учитывая незначительные площади лесов на территории страны. Соответственно, внедрение принципов именно интенсивного лесопользования является единственным путем для активизации работы лесохозяйственных предприятий, обеспечение росте уровня их финансового обеспечения. В статье констатируется, что усовершенствование также требует механизм финансирования этой отрасли, который не соответствует основным принципам функционирования рыночной экономики. Также конкретизированы проблемы в этом направлении развития лесного хозяйства. Ключевые слова: лесное хозяйство, финансовое обеспечение, отрасль лесного хозяйства, интенсивное лесопользование, финансирование лесохозяйственных предприятий.

Forestry is one of the historically formed sectors of economy, the existence of which is due to natural resources of the countries and the creation, use and preservation of which requires constant supervision, especially in those countries where some features of intensive development can be observed. Forest is a renewable resource, and the forestry sector plays an important role in the functioning of many related sectors of economy. Within the article, current systematic problems of the forestry development in Ukraine are considered, and the basic obstacles for the improvement of financial support of the functioning of this sector of the national economy are highlighted. In par- 
ticular, in order to deepen the understanding of the current trends in the functioning of the forestry sector, its basic obstacles and potential for development, a SWOT analysis of forestry enterprises in Ukraine is conducted; strengths, weaknesses, opportunities and threats are pointed out. It is established that in Ukraine today the model of extensive forest use is applied, which has already lost its relevance, as it does not not allow to increase the production of the outlined industry, to ensure its long-term development, given the small area covered with forest in the country. Accordingly, the implementation of the principles of intensive forest use is the only way to intensify the operation of forestry enterprises, to ensure the growth of their financial stability. In particular, it is emphasized, that the intensive model of the forestry enterprises development involves the application of modern technologies to ensure rational use of forest raw materials, to increase the efficiency of its processing. It is stated in the article that the mechanism of the financing of the outlined branch, which does not correspond to the basic principles of the market economy functioning, also needs to be improved. In addition, problems in the direction of the forestry development are specified. Key words: forestry, financial support, branch of forestry, intensive forest use, financing of forestry enterprises.

Постановка проблеми. Лісове господарство $€$ однією з історично сформованих галузей економіки, існування якої зумовлено природними ресурсами країн і створення, використання та збереження яких вимагає постійного нагляду, особливо в тих країнах, де спостерігаються ознаки інтенсивного економічного розвитку. Ліс $€$ відновлювальним ресурсом, а галузь лісового господарства відіграє важливу роль у функціонуванні багатьох суміжних сфрер економіки. Однак таке відновлення можливе лише через збереження лісу, використання схем екстенсивного виробництва. Окреслене вимагає створення таких умов для ведення господарської діяльності в цій сфері, які б дозволяли сформувати баланс між реалізацією підприємницької діяльності, підвищенням ролі лісового господарства в економічному розвитку країни та забезпеченням відновлення лісових ресурсів, їх раціональним використанням з урахуванням збереження екологічних систем, у фрункціонуванні яких ліс відіграє ключову роль. Це на сьогодні потребує впровадження нових технологій у діяльність лісогосподарських підприємств, що обумовлює потребу у фрінансових ресурсах.

Розвиток лісового господарства залежить від загального економічного становища країни, наявності сприятливого інвестиційного клімату, ефрективності роботи державних інститутів та інших чинників. Проте нині в галузі лісового господарства України спостерігається низка проблем, з-поміж яких однією з найбільших є питання забезпечення розвитку лісогосподарських підприємств необхідними фінансовими ресурсами. Відсутність таких коштів значно стримують екстенсивний розвиток цих суб'єктів господарювання і знижують рівень їх конкурентоспроможності в порівнянні з аналогічними підприємствами в інших країнах. Саме така ситуація зумовлює необхідність проведення нових наукових досліджень 3 метою виокремлення деструктивних чинників у розвитку лісового господарства та пошуку рішень нівелювання їхнього впливу.

Аналіз останніх досліджень і публікацій. Особливості фрормування фрінансового забезпечення розвитку діяльності підприємств реально- го сектору економіки висвітлені в наукових працях таких учених: Т. Васильєва, О. Євтушенко, В. Захаров, О. Калмиков, Н. Резнік, Г. Станко, С. Фролов, О. Харковин, А. Череп, І. Чугунов, С. Шкарлет. Питання розвитку лісового господарства як складової частини національного господарства у своїх працях вивчали такі українські вчені: В. Голян, О. Дребот, А. Карпук, Ю. Кільчицький, М. Кизим, К. Кудряшова, В. Мікловда, Н. Попадинець, В. Хаустова, Н. Юрків та інші.

Виділення невирішених раніше частин загальної проблеми, котрим присвячується означена стаття. Незважаючи на наявність ґрунтовних наукових напрацювань у сфрері функціонування лісового господарства, дослідження особливостей розвитку цієї галузі, актуальними залишаються питання конкретизації перешкод активізації роботи лісогосподарських підприємств, виокремлення системних проблем у розвитку всієї галузі.

Формулювання цілей статті (постановка завдання). Метою цієї роботи є дослідження сучасного стану лісового господарства в Україні 3 метою визначення основних перешкод розвитку цієї галузі.

Виклад основного матеріалу дослідження. Варто пам'ятати, що розвиток підприємств лісової промисловості $\epsilon$ необхідною умовою задоволення зростаючого попиту у відповідній продукції як на внутрішньому, так і зовнішніх ринках; зростання рівня зайнятості та зниження рівня соціального напруження в територіальних системах регіонів України; підвищення ефрективності використання ресурсного та інвестиційного потенціалів відповідних територіальних систем; формування дохідної частини місцевих бюджетів; вирішення проблем, які впливають на вихід таких систем на траєкторію сталого розвитку [13, c. 92].

Проведемо детальне вивчення базових проблем у розвитку галузі лісового господарства та її фрінансового забезпечення. Вагому увагу приділимо опису перешкод, які існують в Україні загалом у цій сфері господарювання та акцентуємо на проблемах фінансового забезпечення роботи лісогосподарських підприємств. 
Для поглиблення розуміння сучасних тенденцій функціонування галузі лісового господарства, іiі базових перешкод та потенціалу до розвитку проведемо SWOT-аналіз діяльності лісогосподарських підприємств в Україні. Відповідна матриця сильних, слабих сторін, можливостей та загроз представлена в табл. 1.

Аналізуючи інформацію табл. 1, статистичні дані щодо функціонування галузі лісового господарства в Україні як єдиної макроекономічної системи, можливо констатувати наявність таких перешкод у її розвитку:

1) низький середній рівень лісистості території країни;

2) неврегульований ринок деревини та відсутність порядку її реалізації на внутрішньому ринку, через що процвітає нелегальний ринок;

3) половина лісів України $є$ штучно створеними і потребують посиленого догляду;

4) недостатнє бюджетне фрінансування лісового господарства для Півдня і Сходу країни;

5) відсутність адміністративної і кримінальної відповідальності за переробку краденої деревини та слабкі функції лісової охорони;

6) відсутність глибокої переробки деревини на підприємствах малого і середнього бізнесу, особливо в депресивних районах Карпат і Полісся;
7) застарілі правила рубок, що не враховують сучасні технології та екологічність їх проведення;

8) частина площі лісів зростає в зоні радіоактивного забруднення;

9) зростання експорту необробленої деревини;

10) неврегульований ринок деревини та відсутність порядку ії реалізації на внутрішньому ринку, через що процвітає нелегальний ринок $[12$, c. 120].

Однак більш детальний розгляд економічних процесів, що відбуваються у межах окресленої сорери господарювання, дозволяє констатувати наявність глибших, системних проблем у діяльності лісогосподарських підприємств, які потребують свого вирішення. Насамперед досвід зарубіжних країн і сучасні тренди в забезпеченні розвитку національних економік на засадах сталості, ефективності використання всіх наявних та необхідних для розвитку господарюючих суб'єктів, застосування енергозберігаючих технологій та раціонального споживання енергії свідчить про необхідність зміни взагалі концептуальних, парадигмальних засад функціонування лісогосподарських підприємств в Україні.

На рис. 1 представлено результати систематизації базових проблем, що стримують загалом

\section{SWOT-аналіз галузі лісового господарства}

\begin{tabular}{|c|c|}
\hline СИЛЬНІ с & UЛADNICIURO \\
\hline $\begin{array}{l}\text { - наявність попиту на лісову сирови- } \\
\text { ну як на внутрішньому, так і на зов- } \\
\text { нішньому ринках; } \\
\text { - наявність кваліфікованих працівни- } \\
\text { ків; } \\
\text { - існування закладів освіти, які готу- } \\
\text { ють відповідних спеціалістів, науко- } \\
\text { вих установ, що провадять свою ді- } \\
\text { яльність у сорері дослідження різних } \\
\text { аспектів лісового господарства; } \\
\text { - розвиток екологічної культури міс- } \\
\text { цевого населення; }\end{array}$ & $\begin{array}{l}\text { - високий рівень корупції та тіньової економіки; } \\
\text { - низький рівень лісистості території країни; } \\
\text { - недостатній розвиток нормативно-правового забезпечення розвитку } \\
\text { лісового господарства; } \\
\text { - тривалий (близько } 100 \text { років) виробничий цикл лісовирощування та } \\
\text { високий термін окупності витрат; } \\
\text { - підпорядкованість держлісгоспів різним міністерствам і відомствам, } \\
\text { адміністративні методи визначення виду й місця рубки; } \\
\text { - невідповідність обсягів ресурсів лісової сировини та виробничих по- } \\
\text { тужностей щодо їхньої переробки; } \\
\text { - нееорективний механізм захисту та догляду за лісами; } \\
\text { - недостатньо розвинута інфраструктура лісового господарства Укра- } \\
\text { їни; } \\
\text { - висока частка (близько } 48 \text { \%) застарілого та фрізично зношеного об- } \\
\text { ладнання; }\end{array}$ \\
\hline & \\
\hline $\begin{array}{l}\text { - значний по } \\
\text { виробництва } \\
\text { вої сировини } \\
\text { ної вартості; } \\
\text { - зручне гес } \\
\text { близькі зовні } \\
\text { - наявність г } \\
\text { ку рекреацій } \\
\text { - диверсиф } \\
\text { яльності та } \\
\text { рел фрінансо } \\
\text { - поглиблен } \\
\text { ресурсів, пе } \\
\text { робки дерев }\end{array}$ & $\begin{array}{l}\text {-либлення макроекономічної нестабільності та погіршення фінан- } \\
\text { го забезпечення лісогосподарських підприємств; } \\
\text { нсервація існуючої моделі державного регулювання галузі лісово- } \\
\text { сподарства та управління лісогосподарськими підприємствами; } \\
\text { сутність зміни моделі фінансування діяльності лісогосподарських } \\
\text { оиємств, що не дозволить залучати приватні інвестиції для їх роз- } \\
\text { у; } \\
\text { еншення обсягів лісистості країни у випадку несанкціонованих ви- } \\
\text { к лісу, особливо в Карпатах та в Поліссі; } \\
\text { лередбачувані природні катаклізми, що знищують значні території } \\
\text { (пожежі, повені, активізація ерозійних процесів); } \\
\text { ріцит коштів на охорону й відтворення лісів; }\end{array}$ \\
\hline
\end{tabular}

Джерело: складено автором на основі [6; 7; 9; 21]. 


\section{ПРОБЛЕМИ РОЗВИТКУ ГАЛУЗІ ЛІСОВОГО ГОСПОДАРСТВА В УКРАЇНІ}

\section{ПРИРОДНІ ТА КЛІМАТИЧНІ}
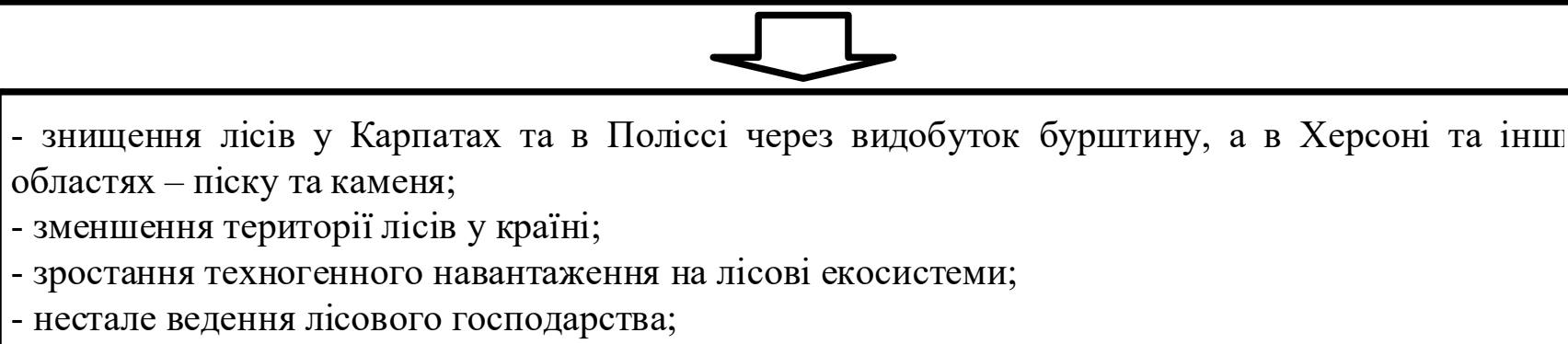

\section{ПРАВОВІ, ОРГАНІЗАЦІЙНІ ТА ІНФОРМАЦІЙНІ}

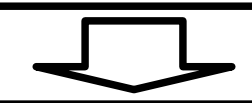

- правова неврегульованість питань щодо вирощування, заготівлі та перероблення деревини;

- неврегульований ринок деревини та відсутність порядку їі реалізації на внутрішньому ринку;

- відсутність адміністративної і кримінальної відповідальності за переробку краденої деревини слабкі функції лісової охорони;

- застарілі правила рубок, що не враховують сучасні технологї та екологічність їх проведення; - відсутність правових та економічних механізмів стимулювання запроваджен природоощадних технологій або їхніх елементів, охорони, захисту, відновлення лісів;

- суцільні необгрунтовані рубки, особливо в Національних парках;

- виконання державою функцій нормування та контролю, власника й суб'єкта господарювання;

- відсутність єдиної відповідної інформаційної бази щодо діяльності не лише Державно

агентства лісових ресурсів, а й інших міністерств у віддані яких знаходяться ліси;

- відсутність участі громадськості у формуванні та реалізації державної лісової політики врахуванням інтересів усього суспільства та місцевих громад;

- недоцільне поєднання лісогосподарськими підприємствами функцій 3 ведення лісово господарства та перероблення деревини;

\section{ЕКОНОМІЧНІ ТА ФІНАНСОВІ}

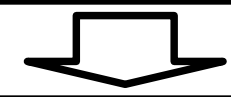

\section{- збільшення експорту необробленої деревини, яке призвело до критичних відносин} деревообробниками;

- відсутність глибокої переробки деревини на підприємствах малого і середнього бізнесу;

- екстенсивність лісокористування;

- недостатнє державне фінансування;

- недостатня якість вітчизняної продукцї̈ для її конкурентоспроможності на зовнішніх ринках;

- відсутність економічного механізму стимулювання запровадження природо зберігаюч] технологій або їх елементів;

- недостатня прозорість фінансових потоків, пов’язаних із експортними операціями;

- недостатній досвід торгівлі ресурсами необробленої деревини із зарубіжними країнами;

- значні митні бар’єри для експорту лісопродукції підприємств недержавної форми власності.

Рис. 1. Актуальні проблеми розвитку галузі лісового господарства в Україні Джерело: систематизовано авторами на основі [4; 5; 15; 17; 18; 22] 
розвиток галузі лісового господарства в Україні.

Варто розуміти, що перехід функціонування лісогосподарських підприємств на нову модель власного існування повинна супроводжуватися також зміною вектора розвитку всієї галузі лісового господарства, що полягає в переході від інтенсивного способу виробництва лісової сировини до екстенсивної моделі ії̈ продукування. Розглянемо докладніше окреслені моделі функціонування таких суб'єктів господарювання.

Екстенсивна модель розвитку лісового господарства - це модель, яка будується на засадах активного використання наявних лісових територій, зростання обсягу виробництва за рахунок збільшення площ вирубок лісів. До основних особливостей такої моделі варто віднести такі:

- використовується в країнах, які володіють значними лісовими масивами і питання щодо ефективності та раціональності використання лісових ресурсів є другорядним;

- використання інноваційних технологій у виробництві лісової сировини та продукції залишається на досить низькому рівні, оскільки у наявності значні обсяги лісових масивів;

- лісові господарства прибуток отримують лише один раз - у результаті фрінальної рубки та продажу сировини [8, с. $48 ; 10$, с. 146$]$.

Інтенсивна модель розвитку лісогосподарських підприємств передбачає використання сучасних технологій для забезпечення раціонального використання лісової сировини, правильної іï̈ заготівлі. Інтенсивне лісокористування найбільш розвинуте у Швеції і Фінляндії. Шведсько-фрінська («скандинавська») модель інтенсивного лісокористування побудована насамперед на створенні правильної системи проведення рубок догляду: за лісом доглядають так, як за городом, забезпечуючи вихід певних лісоматеріалів [8, с. 48].

До основних особливостей цієї моделі варто віднести такі:

- використовується в країнах, де є дефіцит лісових ресурсів і незначний рівень лісистості;

- супроводжується розробкою, імпортом та впровадженням нових технологій виробництва лісових ресурсів, використанням нового обладнання;

- пов'язана з активним впровадженням нових екологічних технологій, підвищенням захисту навколишнього середовища;

- використовується при фрормування умов для розвитку лісогосподарських підприємств на засадах сталого лісокористування та ін.

Аналіз окремих характерних рис окреслених вище моделей розвитку галузі лісового господарства дає можливість зробити висновок, що в Україні на сьогодні використовується модель інтенсивного лісокористування, проте рівень лі- систості території в нашій країні $€$ недостатнім у порівнянні $з$ іншими розвинутими країнами. Це ще раз підтверджує необхідність зміни ссоормованої моделі функціонування всієї галуз лісового господарства. Цілком зрозуміло, що без такої трансформації, фрормування нових умов для роботи лісогосподарських підприємств, забезпечити активну розбудову цієї галузі неможливо. Також варто констатувати, що активне використання моделі інтенсивного розвитку надалі може призвести лише до уповільнення і так незначного рівня розбудови лісової галузі, оскільки площі лісових ресурсів будуть скорочуватися 3 більшою швидкістю.

Специфіка розбудови галузі лісового господарства полягає в тому, що ця сфера є реальним сектором економіки, яка продукує матеріальні ресурси, товари для їх подальшого споживання. Відповідно, маючи справу з конкретним видом ресурсів та сировини, лісогосподарські підприємства постійно зобов'язані впроваджувати сучасні технології для підвищення рівня раціональності їх використання, поглиблення рівня обробки сировини та фрормування нових, якісних товарів і продукції. Відповідно, впровадження сучасних інноваційних технологій вимагає відповідного фрінансового забезпечення. Однак у цій частині розвитку окресленої ссрери в Україні вже накопичилася значна кількість системних проблем. До їх числа варто віднести такі:

1) низький рівень платоспроможності лісогосподарських підприємств;

2) недостатнє бюджетне фрінансування діяльності лісогосподарських підприємств, що негативно впливає на їхній загальний фрінансовий стан;

3) витрачання власних коштів лісогосподарських підприємств на впровадження загальнодержавних заходів щодо збереження лісів (охорона лісів, захист від шкідників, профілактика заходів щодо унеможливлення лісових пожеж);

4) інвестиційна непривабливість галузі для залучення зовнішніх ресурсів;

5) неефективна фрінансова політика держави у сорері підтримки лісогосподарських підприємств, яка не враховує особливості їх функціонування, специфічні риси лісової галузі;

6) неефективно працюючий механізм фрінансової мотивації керівників та працівників лісогосподарських підприємств, низький середній рівень заробітної плати в галузі;

7) недостатня прозорість фрінансової діяльності лісогосподарських підприємств;

8) низький рівень диверсифрікації надходжень від різних видів діяльності лісогосподарських підприємств;

9) відсутність збалансованої та системної фрінансової підтримки держави; 
10) низька якість фрінансового контролю, що проводиться у межах перевірки роботи лісогосподарських підприємств;

11) великі проценти під кредитні ресурси комерційних банків, які роблять невигідними навіть не надто капіталомісткі проєкти в лісогосподарському виробництві;

12) необхідність лісогосподарським підприємствам виплачувати дивіденди та перераховувати частину отриманого прибутку до бюджетів різних рівнів [1] та інші фрінансові проблеми.

Також одним із недоліків фрінансового забезпечення роботи лісогосподарських підприємств $€$ використання кошторисного методу фрінансування їхньої діяльності. Кошторисне фрінансування лісового господарства здійснюється тому, що підприємства цієї галузі в сучасних умовах не мають достатньо коштів для фрінансування своєї діяльності через низьку прибутковість, а також тому, що охорона й відтворення, захист лісів мають надзвичайно важливе загальносуспільне значення [2, с. 33].

Також однією зі складних проблем у розвитку лісогосподарських підприємств в Україні $є$ необхідність забезпечення їх функціонування вже в нових економічних реаліях, які на сьогодні активно впроваджуються всіма розвинутими країнами. Передусім це використання моделі сталого лісокористування, яка полягає в забезпеченні реалізації не лише економічної функції лісогосподарськими підприємствами, але й підтримку розвитку соціальних та екологічних систем, які 3 ними пов'язані. Відповідно, дотримання такої моделі господарювання також вимагає наявності відповідного фінансового забезпечення.

Сталий розвиток лісового господарства має на меті лісокористування, яке не виснажує ліси та сприяє збереженню особливо цінних лісових ділянок і біорізноманіття. Інструментом управління лісами на принципах сталого розвитку $є$ лісова сертифікація FSC [16].

Лісова Опікунська Рада (Forest Stewardship Council) була створена у 1993 р. за ініціативи низки екологічних організацій, лісових компаній, трейдерів та інших зацікавлених сторін, для підтримки екологічно прийнятного, соціально захищеного та водночас економічно вигідного ведення лісового господарства. Вона виникла завдяки активній діяльності громадських природоохоронних організацій, занепокоєних стрімким скороченням тропічних лісів внаслідок варварської лісозаготівлі та продажем нелегальної деревини на світових ринках. Підтримання балансу та врахування трьох складових - екологічної, соціальної та економічної - $є$ ключовим принципом діяльності FSC [16].

Таким чином, модель сталого лісокористування може бути охарактеризована такими ознака- ми $[3 ; 14 ; 19 ; 20]$ :

1) ефрективне використання лісових ресурсів, запровадження виключно інтенсивної моделі розвитку лісогосподарської галузі;

2) забезпечення екологічного розвитку лісових територій, створення умов для життєдіяльності диких тварин, підтримка звичних для них умов життя;

3) активна співпраця з місцевими громадами та населенням, реалізація спільних проєктів;

4) використання екологічно безпечних засобів та технологій для виробництва лісової сировини, ії̈ транспортування та обробки;

5) співпраця із сільськогосподарськими підприємствами, які здійснюють свою діяльність на території, що є близькою до лісових масивів, унеможливлення впливу результатів ведення сільського господарства (використання добрив, обробка полів пестицидами, розширення територій сільськогосподарських угідь і т. ін.) на умови вирощування лісу;

6) співробітництво з підприємствами водного господарства, забезпечення спорудження гребель та захист лісових територій від підтоплень, заболочення, що впливає на ефективність лісокористування;

7) забезпечення збереження рідкісних видів лісів;

8) активне використання лісу в рекреаційних цілях, побудова відповідної інфрраструктури та ін.

Проте нині в Україні питання щодо запровадження моделі сталого лісокористування постає перед низкою проблем різного характеру. Однією з них є відсутність відповідних фрінансових ресурсів та наявність недосконалої нормативно-правової бази ведення лісогосподарської діяльності, що не дозволяє суб'єктам господарювання бути більш гнучкими у власній діяльності 3 метою забезпечення умов для сталого розвитку. Цілком погоджуємося з позицією І. В. Охременко, що лісове господарство на сьогодні в Україні переходить до стадії інтенсивного екологічно незбалансованого лісокористування. Попри покращення економічних показників ведення лісового господарства одночасно спостерігається погіршення екологічного рівня. Так, багато найважливіших елементів лісового господарства, зокрема й охорона лісів, лісовпорядкування, інвентаризація лісів, лісовідновлення, захисне лісорозведення практично не розвиваються і перебувають на низькому рівні. Варто також зазначити, що податкові надходження до бюджету країни не покривають необхідних коштів на охорону та відтворення природних ресурсів у лісовому господарстві [11, с. 61].

Висновки. Отже, у статті проаналізовано базові проблеми розвитку лісового господарства в Україні, значна увага була приділена досліджен- 
ню питань фрінансового забезпечення діяльності лісогосподарських підприємств. У результаті встановлено, що сучасна модель розвитку окресленої галузі й модель ії̈ фрінансування $є$ застарілою і не відповідає сучасним тенденціям та вимогам, які висуваються до роботи окреслених суб'єктів господарювання в розвинутих країнах.

Цілком логічним $\epsilon$ те, що подальше фрункціонування галузі лісового господарства в Україні пов'язано з впровадженням принципів сталого лісокористування. Саме цей підхід є сьогодні магістральним у роботі лісогосподарських підприємств у переважній більшості розвинутих країн. Забезпечення збалансованого розвитку екологічних, соціальних та економічних систем, які $€$ дотичними до функціонування лісового господарства та окремих підприємств у цій галузі, $є$ єдино правильним шляхом для забезпечення активної розбудови цієї галузі в майбутньому. Відповідно, шляхи, які дозволяють сформувати відповідну модель економічної діяльності у лісогосподарському комплексі країни, заходи для підвищення фрінансування роботи відповідних підприємств у цій сфрері $є$ пріоритетними питаннями для проведення додаткових досліджень у подальшому.

\section{БІБЛІОГРАФІЧНИЙ СПИСОК:}

1. Офріційний вебсайт Державної служби статистики України. URL: http://www.ukrstat.gov.ua/ (дата звернення 1. Бондар В. Лісове господарство потребує додаткових інвестицій. Zaxid.net. URL: https://zaxid.net/lisove_ gospodarstvo_potrebuye_dodatkovih_i nvestitsiy_n1419393.

2. Голян В. А., Голуб О. А. Фінансове забезпечення пріоритетів розвитку лісогосподарського комплексу: диверсифрікація фрорм і засобів. Проблеми економіки. 2016. № 3. С. 31-39.

3. Голян В. А., Демидюк С. М., Гордійчук А. І. Удосконалення еколого-економічного регулювання лісогосподарського підприємництва: вітчизняні реалії та доцільність імплементації зарубіжного досвіду. Інвестиції: практика та досвід. 2012. № 12. С. 26-28.

4. Дубина М. В., Зінкевич О. В. Теоретичні аспекти функціонування та розвитку лісового господарства в Україні. Бізнес Інфоорм. 2020. № 2. С. 187-192.

5. Жаворонок А. Комплексне оцінювання фінансового стану підприємств лісогосподарської галузі як передумова залучення фінансових ресурсів. Галицький економічний вісник. 2020. Том 65. № 4. С. 138-150.

6. Жаворонок А. В., Ковальчук Н. О. Особливості фінансового забезпечення вітчизняних підприємств лісового господарства. Інфраструктура ринку. 2020. № 43. С. 154-159. DOI: https://doi.org/10.32843/infrastruct43-28.

7. Кичко І. І., Гарус Ю. О. Перспективи розвитку лісового господарства України. Глобальні та національні проблеми економіки. 2016. Вип. 1. С. 128-132.

8. Корчагов С. А., Конюшатов О. А. Нормативно-правовая база для интенсивного лесного хозяйства на федеральном та региональном уровне. Интенсивное устойчивое лесное хозяйство: барьеры и перспективы развития. Москва : WWF России, 2013. С. 45-83.

9. Косач І. Концептуальні засади розробки стратегії розвитку державно-приватного партнерства в АПК України. Проблеми і перспективи економіки та управління. 2018. № 1 (13). С. 24-31.

10. Кудряшова К. М. Модель ефективного розвитку лісового господарства України. Науковий вісник IФHТУНГ. Серія: економіка та управління в нафотовій і газовій промисловості. 2015. № 2 (12). С. 146-150.

11. Охременко І. В. Економічний аналіз сучасного стану лісового господарства України. Вісник ХНТУСГ, 2018. Вип. 197. С. 59-65.

12. Пиріг К. М. Економічні аспекти розвитку лісового господарства в Україні. Вісник Чернігівського державного технологічного університету. 2012. № 2 (58). С. 116-120.

13. Пілько А. Д., Осташук А. М. Оцінка ефективності управління виробництвом на підприємстві лісового господарства: досвід застосування дискримінант них і прикладних економетричних моделей. Бізнес Інформ. 2017. № 7. С. 91-95.

14. Польовський А. М. Еколого-економічні засади удосконалення національної лісової політики : автореф. дис. ... канд. екон. наук : 08.00.06 / Національний лісотехнічний університет України. Львів, 2008. 20 с.

15. Попело О. В. Інноваційно-інвестиційна домінанта в регіональному розвитку продуктивних сил. Проблеми і перспективи економіки та управління. 2018. № 3 (15). С. 112-129.

16. Сталий розвиток лісового господарства. wwf.ua. URL: https://wwf.ua/our-work/forest/sustainable-forestry/.

17. Холявко Н. І. Сучасні інформаційні технології в роботі фрінансових установ. Бізнес Інфрорм. 2021. № 5. C. $152-161$.

18. Холявко Н. І., Колоток М. О. Інформаційні технології в роботі зарубіжних фрінансових установ. Проблеми і перспективи економіки та управління. 2021. № 1 (25). С. 117-126.

19. Юрків Н. М. Побудова моделі процесу формування стратегій еколого-безпечної експортної діяльності лісогосподарських підприємств. Науковий вісник НЛТУ України. 2018. Т. 28, № 4. С. 128-131.

20. Ярема І. І. Напрямки стимулювання сталого використання лісоресурсного потенціалу гірських територій державними лісогосподарськими підприємствами. Регіональна економіка. 2012. № 2. С. 194-199.

21. Popelo O. Analysis of resource potential of Ukraine regions. Проблеми і перспективи економіки та управління. 2018. № 2 (14). С. 64-83.

22. Popelo O. Analysis of the level of ecological sphere modernization as a component of the productive forces modernization of the Ukraine regions. Проблеми і перспективи економіки та управління. 2018. № 1 (13). С. 98-104. 


\section{REFERENCES:}

1. Bondar, V. (2017). Lisove hospodarstvo potrebuie dodatkovykh investytsii [Forestry needs additional investment]. Zaxid.net. [in Ukrainian]. URL: https://zaxid.net/lisove_gospodarstvo_potrebuye_dodatkovih_investitsiy_n1419393.

2. Holian, V. A., Holub, O. A. (2016). Finansove zabezpechennia priorytetiv rozvytku lisohospodarskoho kompleksu: dyversyfikatsiia form i zasobiv [Financial support of the forestry complex development priorities: diversification of forms and means]. Problemy ekonomiky - Problems of the economy, (3), 31-39. [in Ukrainian].

3. Holian, V. A., Demydiuk, S. M., Hordiichuk, A. I. (2012). Udoskonalennia ekoloho-ekonomichnoho rehuliuvannia lisohospodarskoho pidpryiemnytstva: vitchyzniani realii ta dotsilnist implementatsii zarubizhnoho dosvidu [Improvement of ecological and economic regulation of forestry entrepreneurship: domestic realities and expediency of the implementation of foreign experience]. Investytsii: praktyka ta dosvid - Investments: practice and experience, (12), 26-28. [in Ukrainian].

4. Dubyna, M. V., Zinkevych, O. V. (2020). Teoretychni aspekty funktsionuvannia ta rozvytku lisovoho hospodarstva $\checkmark$ Ukraini [The theoretical aspects of the functioning and development of forestry in Ukraine]. Biznes Inform - Business Inform, (2), 187-192. [in Ukrainian].

5. Zhavoronok, A. (2020). Kompleksne otsiniuvannia finansovoho stanu pidpryiemstv lisohospodarskoi haluzi yak peredumova zaluchennia finansovykh resursiv [Comprehensive assessment of the financial status of forestry enterprises as a prerequisite for financial resources attraction]. Halytskyi ekonomichnyi visnyk - Galician Economic Bulletin, 65(4), 138-150. [in Ukrainian].

6. Zhavoronok, A. V., Kovalchuk, N. O. (2020). Osoblyvosti finansovoho zabezpechennia vitchyznianykh pidpryiemstv lisovoho hospodarstva [Peculiarities of financial support of domestic forestry enterprises]. Infrastruktura rynku - Market infrastructure, (43), 154-159. [in Ukrainian]. URL: https://doi.org/10.32843/infrastruct43-28.

7. Kychko, I. I., Harus, Yu. O. (2016). Perspektyvy rozvytku lisovoho hospodarstva Ukrainy [Prospects of development of forestry of Ukraine]. Hlobalni ta natsionalni problemy ekonomiky - Global and National Problems of Economy, 1, 128-132. [in Ukrainian].

8. Korchahov, S. A., Koniushatov, O. A. (2013). Normativno-pravovaia baza dlia intensivnogo lesnogo khoziaistva na federalnom ta regionalnom urovne [Regulatory framework for intensive forestry at the federal and regional levels]. In Intensivnoe ustoichivoe lesnoe khoziaistvo: barery i perspektivy razvitiia - Intensive sustainable forestry: barriers and prospects for development (pp. 45-83). WWF Rossii. [in Russian].

9. Kosach, I. (2018). Kontseptualni zasady rozrobky stratehii rozvytku derzhavno-pryvatnoho partnerstva v APK Ukrainy [Conceptual basics for the formation of the strategy of public-private partnership development in Ukrainian $\mathrm{AIC}$. Problemy i perspektyvy ekonomiky ta upravlinnia - Problems and prospects of economics and management, (1(13)), 24-31. [in Ukrainian].

10. Kudriashova, K. M. (2015). Model efektyvnoho rozvytku lisovoho hospodarstva Ukrainy [Model of effective development of forestry in Ukraine]. Naukovyi visnyk IFNTUNH. Seriia: ekonomika ta upravlinnia $v$ naftovii $i$ hazovii promyslovosti - Scientific Bulletin IFNTUNG. Series: economics and management in the oil and gas industry, (2(12)), 146-150. [in Ukrainian].

11. Okhremenko, I. V. (2018). Ekonomichnyi analiz suchasnoho stanu lisovoho hospodarstva Ukrainy [Economic analysis of the modern condition of the forestry of Ukraine]. Visnyk KhNTUSH - Bulletin of KhNTUSG, 197, 59-65. [in Ukrainian].

12. Pyrih, K. M. (2012). Ekonomichni aspekty rozvytku lisovoho hospodarstva v Ukraini [Economic aspects of the forestry development in Ukraine]. Visnyk Chernihivskoho derzhavnoho tekhnolohichnoho universytetu - Bulletin of Chernihiv State Technological University, (2(58)), 116-120. [in Ukrainian].

13. Pilko, A. D., Ostashuk, A. M. (2017). Otsinka efektyvnosti upravlinnia vyrobnytstvom na pidpryiemstvi lisovoho hospodarstva: dosvid zastosuvannia dyskryminant nykh i prykladnykh ekonometrychnykh modelei [The evaluation of efficiency of production management at forestry enterprise: experience with discriminantal and applied econometric models]. Biznes Inform - Business Inform, (7), 91-95. [in Ukrainian].

14. Polovskyi, A. M. (2008). Ekoloho-ekonomichni zasady udoskonalennia natsionalnoi lisovoi polityky [Ecological and economic principles of improving the national forest policy] [PhD dissertation, Natsionalnyi lisotekhnichnyi universytet Ukrainy]. [in Ukrainian].

15. Popelo, O. V. (2018). Innovatsiino-investytsiina dominanta $v$ rehionalnomu rozvytku produktyvnykh syl [Innovation-investment dominant in regional development of production forces]. Problemy i perspektyvy ekonomiky ta upravlinnia - Problems and prospects of economics and management, (3(15)), 112-129. [in Ukrainian].

16. Stalyi rozvytok lisovoho hospodarstva [Sustainable development of forestry]. (n.d.). wwf.ua. [in Ukrainian]. URL: https://wwf.ua/our-work/forest/sustainable-forestry.

17. Kholiavko, N. I. (2021). Suchasni informatsiini tekhnolohii v roboti finansovykh ustanov [Modern information technologies in the activities of financial institutions]. Biznes Inform - Business Inform, (5), 152-161. [in Ukrainian].

18. Kholiavko, N. I., Kolotok, M. O. (2021). Informatsiini tekhnolohii v roboti zarubizhnykh finansovykh ustanov [Information technologies in the activities of foreign financial institutions]. Problemy i perspektyvy ekonomiky ta upravlinnia - Problems and prospects of economics and management, (1(25)), 117-126. [in Ukrainian].

19. Yurkiv, N. M. (2018). Pobudova modeli protsesu formuvannia stratehii ekoloho-bezpechnoi eksportnoi diialnosti lisohospodarskykh pidpryiemstv [Construction of the model of the strategies formation of the environmemtally friendly export activity of forestry enterprises]. Naukovyi visnyk NLTU Ukrainy - Scientific Bulletin of UNFU, 28(4), 128-131. [in Ukrainian]. 
20. Yarema, I. I. (2012). Napriamky stymuliuvannia staloho vykorystannia lisoresursnoho potentsialu hirskykh terytorii derzhavnymy lisohospodarskymy pidpryiemstvamy [Directions of stimulation of mountain areas forestry potential sustainable use by the state forestry enterprises]. Rehionalna ekonomika - Regional economy, (2), 194199. [in Ukrainian].

21. Popelo, O. (2018). Analysis of resource potential of Ukraine regions. Problems and prospects of economics and management, (2(14)), 64-83.

22. Popelo, O. (2018). Analysis of the level of ecological sphere modernization as a component of the productive forces modernization of the Ukraine regions. Problems and prospects of economics and management, (1(13)), 98104. 